\title{
ARE THE 100 BEST SPA HOTELS IN POLAND REALLY SPA CENTERS?
}

\section{CZY 100 NAJLEPSZYCH HOTELI SPA W POLSCE TO RZECZYWIŚCIE OŚRODKI SPA?}

\author{
Elżbieta Biernat $^{1(\mathrm{~A}, \mathrm{C}, \mathrm{D}, \mathrm{E}, \mathrm{F}, \mathrm{G})}$, Katarzyna Sempolska $^{2(\mathrm{~B}, \mathrm{G})}$, Nadia Shmakova $^{1(\mathrm{E})}$ \\ ${ }^{1}$ Warsaw School of Economics, Poland \\ ${ }^{2}$ College of Engineering and Health in Warsaw, Poland
}

\begin{abstract}
Authors' contribution
Wkład autorów:

A. Study design/planning zaplanowanie badań B. Data collection/entry zebranie danych

C. Data analysis/statistics dane - analiza i statystyki D. Data interpretation interpretacja danych E. Preparation of manuscript przygotowanie artykułu F. Literature analysis/search wyszukiwanie i analiza literatury G. Funds collection zebranie funduszy
\end{abstract}

Tables: 3

Figures: 0

References: 30

Submitted: 2018 Dec 16

Accepted: 2019 Feb 18

\begin{abstract}
Summary
Background. In the face of unrelenting civilization threats and social challenges, the dynamic development of wellness \& spa centers is observed. The aim of this work is an analysis to determine whether the 100 best Polish spa hotels satisfy the requirements of this type of company in light of terminology put forward by the International Spa Association (ISPA) and the European Spas Association (ESPA).

Material and methods. Definitions put forward by ISPA and ESPA form the basis of assessment in this study. A method of diagnostic survey was applied.

Results. According to the ESPA, only $41 \%$ of spas can actually be classified as such, compared to $61 \%$ according to ISPA. As many as $22 \%$ of the hotels surveyed do not meet the requirements of such enterprises for either ESPA or ISPA. Inconsistent definitions of ESPA and ISPA lead to chaos in the wellness \& spa market.

Conclusions. It is necessary to develop a Polish definition which clearly defines the criteria for the classification of spa facilities and the possibility of their verification from the point of view of quality and compliance with planned standards.
\end{abstract}

Keywords: Poland, spa centers, definitions, International Spa Association, European Spas Association

\section{Streszczenie}

Wprowadzenie. W obliczu niesłabnących zagrożeń cywilizacyjnych i wyzwań społecznych obserwuje się dynamiczny rozwój ośrodków wellness \& spa. Celem pracy jest analiza, czy w świetle terminologii International Spa Association (ISPA) i The European Spas Association (ESPA), 100 najlepszych polskich hoteli spa rzeczywiście spełnia wymogi tego typu przedsiębiorstwa.

Materiał i metody. Podstawą oceny są przyjęte przez ISPA i ESPA definicje spa. Zastosowano metode sondażu diagnostycznego.

Wyniki. Według kryteriów ESPA tylko 41\% hoteli może być określonych mianem spa, według ISPA - tylko $61 \%$. Aż $22 \%$ ze wszystkich badanych hoteli nie spełnia kryteriów ESPA i ISPA. Niespójne definicje ESPA i ISPA prowadzą do chaosu na rynku wellness \& spa.

Wnioski. Konieczne jest opracowanie ustawowej polskiej definicji, która określi normy/ kryteria klasyfikacji obiektów spa i umożliwi ich weryfikację pod względem jakości i zgodności z wyznaczonymi standardami.

Słowa kluczowe: Polska, ośrodki spa, definicje, International Spa Association, European Spas Association

\section{Introduction}

The etymology of the word spa is not entirely explained. Some place its origins in Latin, saying it means "health through water" (sanitas per aquas) or "healthy by water" (sanus per aquam) [1]. Others say it comes from the Walloon "espa" (fountain), the Latin for "spagare" (moisture, spray) or from Belgium (from the town of Spa in the foothills of the Ardennes) where curative thermal springs were discovered in the $16^{\text {th }}$ century. Just understanding the concept also poses many difficulties [2]. The International Spa Association defines a spa as a place of business through which the customer feels a general sense of personal well-being, with a range of different services aimed at renewal of the mind, body, and spirit [3]. The European Spas Association defines a spa as a mineral water source, place or locality where this type of source has been discovered and is used to improve health [4]. The first definition indicates the diversity of services that lead to physical, mental, and spiritual wellbeing (renewal, relaxation, unwinding, stress relief, stimulation or calmness, harmony of body and soul, good 
fun, etc.) [5]. Essentially, this is convergent with the concept of wellness, which can be misleading due to the broader meaning of the term wellness [6]. It is not a product or service that you can buy or sell, but a state of mind [7]. From wellness a client will expect education, consulting, and coaching (which do not need a spa element at all) [8]. The spa is an integral part of the concept of wellness, situated in the area of services and body treatments (health, physiotherapy, therapeutic, cosmetic and beauty) [9].

The second definition which defines a spa as a place where natural medicinal raw materials exist (implicitly a spa) and also as a company/group of companies which provide health services and specific treatments and activities based on natural resources [4]. At the same time, while in the European sense, the spa activity is based on natural medicinal raw materials, in the American sense (ISPA), this is not a requirement. Due to these inconsistencies, the term 'spa' in Poland includes both facilities which base their activities on the idea of a spa (based on a clear concept, not a collection of individual, often randomly-selected treatments) and other entities, such as fitness clubs, wellness centers, beauty salons, and training and conference centers (offering simple beauty treatments as hotel services) [2]. Currently, there is no lack of pseudo-spa facilities which use a variety of words in their name to underline their uniqueness or interdisciplinary nature, like car spa, drinks spa, or 'agrotourism' spa. This linguistic misuse is the result of the lack of a statutory definition in Polish law. Therefore, very often this word is treated as a hypnotic marketing message with which to guarantee market success.

Resultantly, what can customers expect and which kind of center should they choose? This is a difficult question in the context of the terminological chaos described above and the lack of Polish standards or criteria available for the clear classification of spa facilities. Rather, the choice is based on general impressions, associations, emotions, and opinions of the customer. Increasingly, customers acutely feel the lack of verification which might support the accuracy of a selection and the desired levels of service and quality (meaning, on the one hand, meeting the requirements of the purchaser and his stated or implied needs and, on the other hand, compliance with established standards) [10].

Obviously, observing standards (International Organization for Standardization standards - ISO 9000 series) in Polish hotel facilities with a specific category is mandatory [11]. However, one should be aware that in service units providing intangible services, such as, for example, spa (where the essence of the system is the customer's attitude and their expectations of a special character), the ISO management system itself is insufficient. Tools and procedures related to the examination of the client's needs and expectations, as well as his/her satisfaction, are of a very general nature.

Unfortunately - so far - there are no developed quality management systems in Poland in this segment. It is true that efforts have been made for several years in the Polish market to address the problems with terminology and standards, but there is still a long way to go. An important and necessary basis for these activities is to improve services and ensure the possibility of verifying such services, through a system of certification for example. In Poland, the criteria and standards for the operation of spa enterprises are set (and is introducing a system of certification) by a consortium of two companies: Comfortum and the Polish subsidiary of Germanischer Lloyd Sp. z o.o. [12]. Quantitative and qualitative factors are assessed, including water, treatments, equipment, hotel services, gastronomy, and care for harmony of body and mind.

Globally, and in Europe, the spa industry has been developing over the last 30 years or so [13, 14], however, Poland has considerably less experience in this regard. Unfortunately, at present, domestic spa companies rarely belong to global or European associations which guarantee reliability, authenticity, efficiency, and safety. The exceptions are two Dr. Irena Eris hotels (Wzgórza Dylewskie, Krynica Zdrój), which are members of ISPA and certified for quality by Deutscher Wellness Verband, the Premium Quality and Spa Clinic Pod Tężniami in Ciechocinek, which has been certified by ESPA signed EUROPESPA med. Symbols of quality from Deutscher Wellness Verband can also be used by Hotel Król Kazimierz in Kazimierz Dolny, Spa Nałęczów, Palace Thermal Springs and the English Pavilion in Nałęczów-Zdrój, Hotel Malinowy Zdrój in Solec-Zdrój and Hotel Villa Park in Ciechocinek [15]. Obviously, it is pleasing that there is more competition appearing in Poland to find the best holiday accommodation and day spa which stand out in terms of design, interesting architecture, and functionality (e.g. Spa Prestige Awards), or indicative of spa hotels where the cuisine is as important as the luxury accommodation or effective treatment (e.g. the best restaurants in Polish spa hotels). Distinctions of this type are helping the Polish customer by providing knowledge which enables choice of the facility, and in the end a guarantee of customer satisfaction.

However, the important question is whether the quality of the service is repeatable? The lack of its explicit definition means that the client creates his/her own - usually subjective - assessment criteria, and if they are not fulfilled, they simply stop using the given service provider. The more precisely the spa service process is described, the greater the ability to ensure high quality is. The lack of Polish standards/criteria for the classification of objects, coupled with the terminological incoherence already described, may cause a problem 
in the selection of quality assessment criteria. Therefore, the purpose of this work is to fill the gaps created in this area. We analyze whether the 100 best Polish spa hotels (recognized in 2016 by Eden magazine as the best hotels in this industry) actually meet the requirements of this type of enterprise in light of the terminology put forward by the International Spa Association and the European Spas Association. In the era of competition and globalization (including international health tourism), it is also quite important to know whether a foreign tourist considers our center a spa or not. In Poland, there has been no research so far on this subject. Specialists generally pay attention to the fact that as spa services have not been the object of investigation for a long period, there is a lack of empirical research on spa services [16]. Therefore, the aim of this work is to analyze whether the 100 best Polish spa hotels (recognized in 2016 by "Eden Magazine" as the best hotels in this industry) actually meet the requirements of this type of enterprise in light of the terminology put forward by the International Spa Association and the European Spas Association. This kind of study may, from a legislative perspective, provide certain pointers for drawing up the Polish definition of spa, and from a practical point of view, help acquire customers from other geographical areas and build up competitiveness.

\section{Material and methods}

The 100 best spa hotels in Poland were selected for analysis by businessmen and experts from the wellness \& spa industry, journalists promoting the philosophy of wellness and journalists from "SPAeden.pl" and "Eden Magazine" [17]. The data were collected using a telephone interview, which was carried out with the reception of the hotel (in all 26 cases contact was established by email, and in two through a website chat). In addition, the websites of all facilities were analyzed (in nine cases, due to the lack of information, it was only the website of the facility).

The research, conducted from February to April 2017, used an original questionnaire in which interviewees were asked about the characteristics of the hotel: the location (health resort, beyond), the number of stairs, the number of rooms and beds, and the number of treatment rooms. They were also asked about the type of services provided (full-body massages, facial treatments, hydrotherapy treatments), including their nature (included in the price of stay or not). Physical health programs (physical activities, healthy eating, massages, manual treatments, and body renewal rituals) and those concerning mental/spiritual health (learning/practice of philosophy of the East and/or West, health education, personal counseling, special therapies). The infrastructure of the hotel (saunas, cooling zone and consultative-advisory points) was also analyzed. The collected information was supposed to enable an evaluation of whether the inspected hotels are spa centers in the understanding of ESPA and ISPA definitions. According to ISPA, to be qualified as a spa, it is necessary to provide at least 2 of the 3 following services: whole-body massage, dermatological treatments (at least the face), and body treatments (such as hydrotherapy) [3]. The definition also shows that the resort has to provide services for the renewal of mind, body, and spirit. ISPA does not specify whether they must offer all of them or just one. It is also not specified which programs they should implement. Due to the fact that the boundary between activities within individual services is very fluid and difficult to grasp, in the present paper - modeled on Georgiev and Trifonova Vasileva [18] - it was decided to separate two categories of programs implementing the above ISPA guidelines:

1. Physical health - including:

a. physical activities that improve motor skills,

b. healthy eating programs,

c. massages, manual treatments, and rituals of body renewal.

2. Health mental/spiritual - including:

a. learning/practice of philosophy of the East and/or the West (e.g. meditation, yoga, Ayurveda),

b. health education, personal consulting (e.g. psychological, medical, cosmetological),

c. special spiritual renewal therapies (e.g. aromatherapy, chromotherapy).

Due to the fact that customer demand for well-being in the comprehensive approach will grow [19], in this research hotels which firstly provide 2 out of 3 services (full body massages, facial treatments, hydrotherapy treatments), and the second offer a combination of a minimum of three programs selected from two categories (physical and mental/spiritual health) considered to be hotels meeting the ISPA recommendations.

According to ISPA, using natural resources is not an essential condition, whereas it is important for ESPA. Therefore, when comparing the best Polish hotels with the requirements of the ESPA, it was also taken into account whether the hotels were located on the grounds of the spa and whether and how they use the natural resources of the soil, sea, climate, and traditional methods of treatment (e.g. Doctor Kneipp) which, according to ESPA, are fundamental elements in the functioning of a spa facility [4]. Analysis of the results is presented in the upcoming tables. 


\section{Results}

The characteristics of the studied spa hotels are presented in Table 1. All hotels are categorized as hotels with at least 3 stars. Although only $30 \%$ of them are located on the territory of resorts $10 \%$ in mountain health resorts, $4 \%$ in mountain foothills, $8 \%$ in lowland areas, and $8 \%$ in coastal areas), $41 \%$ base their services on natural resources of the soil, sea, climate or traditional methods of treatment.

Table 1. Characteristics of spa hotels $(n=100)$

\begin{tabular}{|c|c|c|}
\hline & Characteristics of spa hotels & \% \\
\hline \multirow{3}{*}{ Hotel category } & $* * * * *$ & 86 \\
& $* * * *$ & 3 \\
\hline & $* * *$ & 26 \\
\hline \multirow{3}{*}{ Number of rooms } & 550 & 20 \\
& $51-100$ & 4 \\
& $101-200$ & 3 \\
\hline Number of beds & $201-300$ & 2 \\
& $>300$ & 23 \\
& 550 & 41 \\
& $51-100$ & 17 \\
& $101-200$ & 7 \\
& $201-300$ & 6 \\
& $301-400$ & 4 \\
\hline \multirow{2}{*}{ Location of hotel } & $401-500$ & 30 \\
\hline
\end{tabular}

In most of the analyzed facilities (79\%), the spa service is included in the stay (see Table 2). The offers include facial treatments, full-body massages (declared in both cases by hotels), and hydrotherapy treatments (58\% of hotels). Analysis of implemented programs showed that physical health programs are most commonly provided, such as massage, manual treatments, and rituals of renewal of the body (pampering and pleasure $-100 \%$, and cosmetic spa-92\%). Programs of mental/spiritual health are rarely offered. At the same time, the most popular services are learning/practice of philosophy of the East and/or West (especially Ayurveda and yoga) - 38\%, and special therapies for spiritual renewal (especially aromatherapy, in a few cases chromotherapy, in one a floatation tank) - 51\%. Programs such as peace of mind are offered by $9 \%$ of the hotels, and stress management - 4\%. All resorts offer packages, usually targeted to different groups of people (e.g. Spa for Friends, Ladies' Privilege, Male Thing, Gift for Parents, Spa for Children, Condition of Seniors, Prescription for the Businessman), long-stay (e.g. Relaxing SPA Weekend for Two, 'SPAntastic') and special occasions (e.g. Romantic Weekend, For Two, Christmas with Spa).

Table 2. Services offered in spa hotels

\begin{tabular}{|c|c|c|}
\hline \multicolumn{2}{|c|}{ Spa services } & $\%$ \\
\hline \multirow{2}{*}{ The price of the services } & included in the price & 79 \\
\hline \multirow{2}{*}{ Type of service } & extra charge & 100 \\
& full-body massages & 100 \\
& facial treatments & 58 \\
\hline
\end{tabular}




\begin{tabular}{|c|c|c|c|}
\hline & Physical health & $\begin{array}{c}\text { physical activities } \\
\text { healthy eating programs } \\
\text { massages, manual treatments, and } \\
\text { rituals of body renewal }\end{array}$ & $\begin{array}{r}56 \\
46 \\
100\end{array}$ \\
\hline Programs & $\begin{array}{l}\text { Mental health/ } \\
\text { spiritual }\end{array}$ & $\begin{array}{l}\text { learning/practice of Eastern } \\
\text { philosophy and/or the West (e.g. } \\
\text { meditation, yoga, Ayurveda) } \\
\text { health education; personal consulting } \\
\text { (e.g. psychological, medical, } \\
\text { cosmetological) } \\
\text { special spiritual renewal therapies } \\
\text { (e.g. aromatherapy, chromotherapy) }\end{array}$ & $\begin{array}{l}17 \\
51\end{array}$ \\
\hline
\end{tabular}

Among the 100 best Polish spa hotels, about 94\% have a sauna (see Table 3). The most common is a dry sauna (93\%), steam bath (60\%), and infrared (35\%). Less frequent are salt sauna (21\%), herbal (16\%), aromatherapy (16\%), mud (6\%), bio-sauna (4\%), ice, Roman, bread, and stone sauna (2\%). A cooling zone is integrated with the sauna area. $92 \%$ of hotels have recreational swimming pools. They are usually filled with chlorinated water $(82 \%)$, but there is also salt water (7\%), spring (4\%), thermal and ozonized (3\%), and sea (1\%) water. Half of swimming pools are equipped with hydro-massages, $34 \%$ counter-currents, $21 \%$ paddling pools, $17 \%$ geysers, $14 \%$ cascades, $13 \%$ slides, $10 \%$ massaging benches, $7 \%$ water slides, $7 \%$ waterfalls, $7 \%$ cannons and water fountains, $4 \%$ massage jets, $2 \%$ showers, and 5\% stream-oriented massages. $83 \%$ of hotels have a hot tub (including, $78 \%$ with chlorinated water, $3 \%$ with thermal and $2 \%$ with chlorine-free water).

Only 5 hotels do not have advisory points. In the others, there is the possibility to consult a cosmetologist (86\%), a physiotherapist (47\%), a trainer (38\%), a doctor (20\%), a dietician (15\%), a psychologist (in one case), and other specialists (a massage therapist - 9\%, chef - 1\%, podologist - 1\%).

Table 3. Spa zone infrastructure in the hotels surveyed

\begin{tabular}{|c|c|}
\hline \multicolumn{2}{|c|}{ Spa zone infrastructure (\%) } \\
\hline Sauna $(42-90 \circ \mathrm{C})$ & 94 \\
\hline Laconium $\left(55^{\circ} \mathrm{C}\right)$ & 15 \\
\hline Caldarium $(20-40 \circ \mathrm{C})$ & 18 \\
\hline Tepidarium $(\sim 36 \circ \mathrm{C})$ & 12 \\
\hline Sanarium & 92 \\
\hline Recreational swimming pool & 83 \\
\hline Hot tub & 20 \\
\hline Shower/shower of impressions & 16 \\
\hline Igloo/ice bowl & 24 \\
\hline
\end{tabular}

Analysis of the 100 best Polish spa hotels in terms of ESPA requirements showed that only $41 \%$ of them can be classified as a spa resort (including those which base their services on the natural resources, sea, and climate, or traditional methods of treatment $-41 \%$, or those located in the area of health resorts - 30\%). ISPA requirements - providing at least 2 out of 3 services and offering at least three programs selected from two categories: physical and mental/spiritual health - were met by $61 \%$ of hotels in total. As many as $22 \%$ of the hotels surveyed do not meet the requirements of such enterprises for either ESPA or ISPA.

\section{Discussion}

This work underlines the fact that the lack of similar notions or understanding and uniform criteria (including the lack of a statutory definition of the word 'spa' in Polish law (Journal of Laws No. 31, pos. 272 [20])) means that 22 of 100 of the top graded spa hotels in Poland (marked out by businessmen and experts from the wellness \& spa industry and journalists who promote philosophy wellness and columnists of the portal "SPAeden.pl" and "Eden Magazine") should not be recognized as spas. Only 41\% satisfy the requirements for this type of resort 
outlined by ESPA, and 61\% those of ISPA. As such, there is an urgent need to develop a Polish statutory definition. Many European countries (like Germany, Austria, Greece, Italy, Lithuania) already have one [10].

The analysis confirms earlier findings by Dryglas [2] that there are currently spa hotels of both the European and American models in Poland. American clients expect more pampering services as value added, which is represented by optional services not intended for medical purposes [21]. Canadians value not only pampering but also healthy food [22]. Europeans seek services which deliver recovery after illness, sanatorium services, medical consultations, etc. [10]. As previous research on spas was more concerned with physical value for a customer, the recent spiritual value provided is increasingly emphasized [23]. People are beginning to appreciate a holistic pattern of spa treatment [10] as an opportunity to improve health (body), escape from emotional pain and stress (spirit) [24], and develop a concept of well-being that encompasses their whole life (mind) [25].

The $21^{\text {st }}$ century is a time of enterprises which understand that today's customers expect maximum use of their time for rest, health, pleasure, integration with family and friends, and getting to know new things, to all matters for which in everyday life he/she is pressed for time [26]. It is time for hotels to realize that the provision of only cosmetological, health and beauty-care services is not enough. Today's customers no longer want to just relax; they want to change. They expect comprehensive programs which lead to bio-psycho-social welfare which, in addition, (due to lack of time) are realized during one stay. Therefore, the (usually) self-service wellness area [27] becomes as important to customers as the spa treatment zone [28]. This is confirmed by observation of the spa market around the globe [24, 29] and in Poland [27]. It shows the common areas of these services, which are closely associated with beauty care, health care and physical and psychological condition [29]. Discovering that many bodily problems are the result of a lack of harmony and a disturbed mental balance is bearing fruit with the need to implement programs for maintaining mental and spiritual health (e.g. inner calm, coping with stress, or eliminating its effects) [29]. This is important in our modern reality, in which building human capital is very significant and in which health is treated as a condition of basic professional and social competence which is used to achieve a better quality of life [30]. Observation of these changes in human lifestyle in the $21^{\text {st }}$ century shows that it is not possible to separate the spa and wellness area, and it is necessary to introduce holistic health-oriented programs which care about health [29]. We are talking here, of course, about the activities of specialized residential hotels whose functions are based on the philosophy of wellness \& spa. Sallmann [27] describes them as those that provide guests with basic services characteristic of each type of hotel (accommodation and meals) and provide the opportunity to use the services and programs characteristic of the wellness \& spa profile (such as healthy eating, physical activities, and the program body and spirit care). On the one hand, they provide information on the protection and maintenance of health; on the other, they offer professional care in the field of healthy eating, physical activity, external appearance, relaxation techniques, and mental education. Unfortunately, Polish research shows that in this type of hotel an important principle, which is the appropriate connection of the spa area with the wellness area, is not always consistently implemented [15].

It is obvious that hotels can specialize, may have a different location and nature (urban, permit, business conference, focused on spiritual development, etc.) and may have a limited or specialized nature of their services. However, it seems that every modern spa hotel (although in different proportions) should implement a basic set of comprehensive spa and wellness services.

In summary, the common goal of wellness \& spa hotels should be to achieve a balance between physical, mental, social and spiritual elements through the application of different procedures and therapeutic methods. The implementation of this goal should be based on both spa (natural healing resources or traditional methods of treatment) and wellness (programs maintaining/improving physical and mental/spiritual health). The proportion in which they are used will allow for the classification of hotels as:

- standard spa and wellness hotels that offer services based on natural medicinal resources and combinations of wellness programs (improving both physical and mental/spiritual health);

- specialized spa and wellness hotels, which will depend on the choice of the combination of elements from each of these concepts.

For example, sea spa and mind wellness will mean a hotel that specializes in caring for mental/spiritual health (by running special programs of spiritual renewal, education, and health counseling or the learning/ practices of the philosophy of the East and/or the West) and which assumes that a large part of treatments and procedures will be based on climate/sea water. Mineral spa and body wellness will mean a hotel which aims to improve physical health (through physical activities, specially designed diet, massage, etc.), and the treatments and procedures will be based largely on spring water.

It seems that such an approach to the problem may, from a legislative perspective, provide some tips on how to develop the Polish definition of spa and develop a quality management system; secondly, it may practically help in attracting clients from different geographical areas and building competitiveness. 


\section{References:}

1. Capellini S. The complete spa book for massage therapists. Clifton Park: Milady; 2009.

2. Dryglas D. Spa and wellness tourism as a spatially determined product of health resorts in Poland. Current Issues of Tourism Research. 2012; 2: 30-38.

3. ISPA [Internet]. Lexington: International Spa Association; 2017. Spa-Goers [cited 2018 Oct 16]. Available from: https://experienceispa.com/resources/spa-goers

4. ESPA EHV. Official Internet Portal of the European Spas Association [Internet]. ESPA EHV; 2018 [cited 2018 Oct 16]. Available from: http://www.espa-ehv.eu/

5. Smith C, Jenner P. Health tourism in Europe. Travel and Tourism Analyst. 2000; 1: 41-59.

6. Kaleta A. [Spa and wellness hotels services as the developmental product of the leisure industry - selected aspects]. Zarządzanie i Finanse. 2012; 1(2): 361-371 (in Polish).

7. Horx-Strathern 0, Horx M, Gaspar C. [What is wellness? Anatomy and future prospects of the wellness trends]. Kelkheim: Eine Publikation des Zukunftsinstituts v. Matthias Horx in Zusammenarbeit mit der GfK Marktforschung; 2001 (in German).

8. Schweder I. The emergence of a new global luxury business model: a case study of the spa at the Mandarin Oriental. In: Cohen M, Bodeker G., editors. Understanding the global spa industry: spa management. Oxford: Butterworth Heinemann; 2008. p. 171-188. https://doi.org/10.1016/B978-0-7506-8464-4.00010-2

9. Dużej K, Kaleta A. [Profiles of individual customers of spa and wellness hotels - outline of problems]. Zeszyty Naukowe Uniwersytetu Szczecińskiego Ekonomiczne Problemy Turystyki. 2012; 4(20): $75-88$ (in Polish).

10. Langviniene M. Specificity of day and resort wellness SPA services in Lithuania. Social Research. 2011; 2(23): 45-58.

11. Kowalczyk J., editor. [Quality standards in tourism. Guidelines for the implementation of the quality standard in a tourist organization]. Warszawa: Ministerstwo Gospodarki i Pracy; 2004 (in Polish).

12. Spa Certyfikat [Internet]. Gdańsk: COMFORTUM TRAVEL \& PROJECTS sp. z o.o. [cited 2018 Oct 16]. Available from: http://spa-certyfikat.pl/ (in Polish).

13. Fontanari M, Kern A. The "Comparative Analyses of Spa" - an instrument for the re-positioning of spas in the context of competition in spa and health tourism. Journal of Tourism Review. 2003; 3(58): 20-28. https://doi.org/10.1108/eb058413

14. Cohen M. Wellness technologies and related products. In: Cohen M, Bodeker G., editors. Understanding the global spa industry: spa management. Oxford: Butterworth Heinemann; 2008. p. $237-257$. https://doi.org/10.1016/B978-0-7506-8464-4.00014-X

15. Mroczek-Czetwertyńska A. [Determinants and perspectives for the development of spa and wellness services market in Lower Silesia] [Doctoral dissertation]. Wrocław: Uniwersytet Ekonomiczny we Wrocławiu, Wydział Ekonomii Zarządzania i Turystyki w Jeleniej Górze; 2013 (in Polish).

16. Koh S, Jung-Eun Joo J, Boger CA. Importance-performance analysis with benefit segmentation of spa goers. International Journal of Contemporary Hospitality Management. 2010; 22(5): 718-735. https://doi.org/10.1108/09596111011053828

17. [100. The best SPA hotels in Poland. Guide to the best places and the most beautiful regions of Poland]. Eden Magazyn SPA \& Wellness; 2016 (in Polish).

18. Georgiev G, Trifonova Vasileva M. Conceptualization and classification of Balneo, SPA and wellness establishments in Bulgaria. UTMS Journal of Economics. 2010; 1(2): 37-44. https://doi.org/10.1016/j.jeconom.2010.03.005

19. PMR Market Experts [Internet]. Kraków: PMR Ltd. Sp. z oo.; 2017. Private healthcare market in Poland 2017. Market analysis and development forecasts for 2017-2022 [cited 2018 0ct 16]. Available from: https://mypmr.pro/products/private-healthcare-market-in-poland-2017

20. [Regulation of the Minister of Health of 17 February 2004 (Journal of Laws, No. 31, item 272)] (in Polish).

21. Molini MM, Krenkel JA, Wirshing JK, Plodkowski RA. Using the wellness benefit for insurance reimbursement of weight loss services at a medically supervised weight management center. Journal of the American Dietetic Association. 2007; 107(8): A50. https://doi.org/10.1016/j.jada.2007.05.089

22. Herarth D, Cranfield J, Henson S. Who consumes functional foods and nutraceuticals in Canada? Results of cluster analysis of the 2006 survey of Canadians' demand for food products supporting health and wellness. Appetite. 2008, 51(2): 256-65.

23. Chen JS, Prebensen N, Huan TC. Determining the motivation of wellness travelers. An International Journal of Tourism and Hospitality Research. 2008; 19(1): 103-115. https://doi.org/10.1080/13032917.2008.9687056

24. Voit C, Brown G, Howat G. Wellness tourists: in search of transformation. Tourism Review. 2011; 66(1/2): 16-30. https://doi.org/10.1108/16605371111127206 
25. Smith M. Holistic holidays: tourism and the reconciliation of body, mind and spirit. Journal of Tourism Recreation and Research. 2003; 28: 15-24. https://doi.org/10.1080/02508281.2003.11081392

26. Smith M. New trends in health and wellness tourism. Budapest: Corvinus University, Institute for Environmental Sciences, Faculty of Business; 2009.

27. Sallmann N. [Wellness \& spa megatrend in leisure-time services market and hotel industry in 21 st century]. Kraków: Wydawnictwo Popularnonaukowe Linea; 2010 (in Polish).

28. Jäger W, Quarch C. [Fitness, wellness and spirituality]. Warszawa: Jacek Santorski \& Co; 2007 (in Polish).

29. Cohen M. Spas, wellness and human evolution. In: Cohen M, Bodeker G., editors. Understanding the global spa industry: spa management. Oxford: Butterworth Heinemann; 2008. p. 1-25. https://doi.org/10.1016/B978-0-7506-8464-4.00001-1

30. Eriksson M. Social capital and health-implications for health promotion. Global Health Action. $2011 ; 4: 5611$. https://doi.org/10.3402/gha.v4i0.5611 